\title{
Two new Carboniferous fertile sphenophylls and their spores from the Czech Republic
}

\author{
Milan Libertín, Jiří Bek, and Jana Drábková \\ Acta Palaeontologica Polonica 53 (4), 2008: 723-732 doi:http://dx.doi.org/10.4202/app.2008.0414
}

Two new species of sphenophyllalean strobili with in situ spores are proposed from the Radnice Basin of the western and central Bohemian Carboniferous continental basins of the Czech Republic. Bowmanites brasensis sp. nov. from Břasy (Matylda Mine) and B. pseudoaquensis sp. nov. from Ovčín locality are determined mainly on the basis of their spores, which are about $100 \mu \mathrm{m}$ in diameter. The thick-walled exine of the miospores is laevigate or sometimes very finely scabrate on the proximal contact area. Spores resemble the dispersed species Punctatisporites obesus. Cones of B. brasensis and B. pseudoaquensis are organically connected with stems having prominent blade leaves and represent a new group of sphenophyllalean strobili.

Key words: Sphenophyllales, Bowmanites, Punctatisporites, spores, Pennsylvanian, Carboniferous, Czech Republic

Milan Libertín [milan_libertin@nm.cz], National Museum, Václavské náměstí 64, 11821 Prague 1, Czech Republic Jiří Bek [mrbean@gli.cas.cz], Laboratory of Palaeobiology and Palaeoecology, Institute of Geology v.v.i., Academy of Sciences, Rozvojová 269, 16500 Prague 6, Czech Republic Jana Drábková [drabkova@cgu.cz], Czech Geological Survey, Klárov 3, 11821 Prague 1, Czech Republic.

This is an open-access article distributed under the terms of the Creative Commons Attribution License (for details please see creativecommons.org), which permits unrestricted use, distribution, and reproduction in any medium, provided the original author and source are credited. 
For Full text $(1,366.1 \mathrm{kB})$ 